\title{
Laudatio to \\ Professor Otto Schück on the Occasion of His 80th Birthday
}

Professor Otto Schück, one of the founders of the Czech Society of Nephrology and its past president, was born on August 26, 1926 in Prague. He graduated from the Medical Faculty of Charles University in Prague in 1950 and became $\mathrm{PhD}$ in the same medical school in 1956.

After graduation he was for less than 1 year a house officer in the Department of Medicine of the Medical Faculty in Pilsen and then he moved to the 1st Department of Medicine of the General University Hospital in Prague where he worked in 1950-1961. The longest period of his scientific life he spent in Prague - Krč, in 19611970 in the Research Institute of the Experimental Therapy, in 1970-1980 in the 3rd Internal Research Base of the Institute of the Clinical and Experimental Medicine and since 1980 until 2005 in the Department of Nephrology of the same Institute. Currently, he is still active as a consultant of the Division of Nephrology of the Department of Medicine in the Faculty Hospital in Prague - Motol.

Dr. Schück became the Associate Professor of Medicine in 1965 and full Professor of Medicine in 1988 in Charles University in Prague. He was the head of the Division of Nephrology of the Institute of the Postgraduate Education in 1980-1995. Dr. Schück spent a year in 1965-1966 as a research fellow at the University of Manchester.

Professor Schück has been a member of many national and international societies, e.g. Czechoslovak and Czech Society of Nephrology (he served as a president of the society in 1990-1996), Slovak Society of Nephrology, International Society of Nephrology, European Renal Association - European Dialysis and Transplantation As-

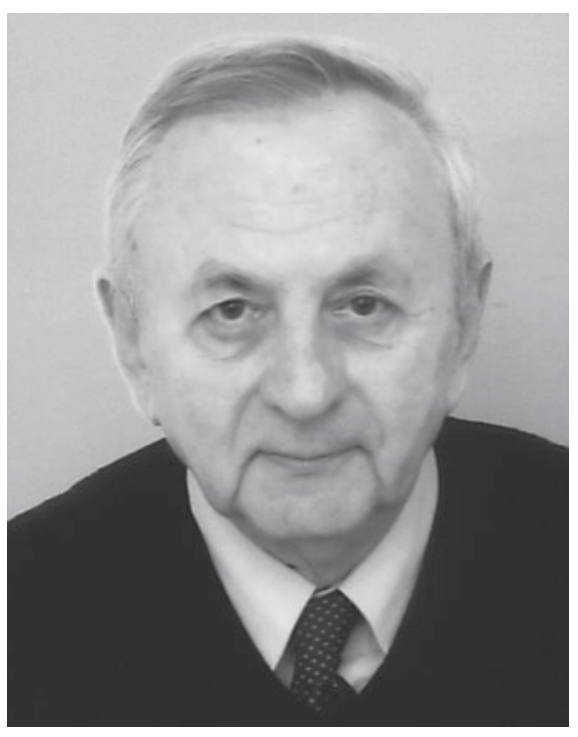

sociation, Czech Society of Internal Medicine, European Society of Internal Medicine, European Society of Clinical Investigation, New York Academy of Sciences and International Society of Clinical Pharmacology.

During his long and yet unfinished scientific career he has obtained many awards, e.g. Jan Brod Award, award of the Czechoslovak and Czech Society of Nephrology, Jan Nedved Award, Bruno Watshinger Award, Award of the Czech Society of Internal Medicine and the Award of the Czech Medical Association.

Professor Schück was a dedicated pregraduate and postgraduate teacher and author of the most important

\begin{tabular}{ll}
\hline KARGER & ( 2006 S. Karger AG, Basel \\
1420-4096/06/0295-0327\$23.50/0 \\
$\begin{array}{l}\text { Fax +4161306 12 34 } \\
\begin{array}{l}\text { E-Mail karger@karger.ch } \\
\text { www.karger.com }\end{array}\end{array}$ & $\begin{array}{l}\text { Accessible online at: } \\
\text { www.karger.com } / \mathrm{kbr}\end{array}$
\end{tabular}


Czech monographs on nephrology: Nephrology for the General Practitioner (six editions 1962-1993, also translated into German and Russian), Clinical Nephrology (1995 with V. Tesar and V. Teplan), The Disorders of the Fluid and Electrolyte Metabolism in Clinical Practice (2000) and Clinical Nephrology (2006 with V. Tesar).

The scientific career of Dr. Schück covers a period of more than 50 years. After graduation (namely in the 50th and early 60th years) Dr. Schück was interested in plasma clearance of different drugs, predominantly antibiotics and cytostatics and published many papers on that issue mainly in pharmacological journals. His concepts gradually evolved to the evaluation of pharmacokinetics and bioavailability of the drugs. In the early years of his scientific career Dr. Schück also studied the resorptive capacity of the urinary bladder and, using radioisotope labeling and autoradiography, the intrarenal distribution of electrolytes (published in Nature in 1959 and 1962). His research interest in the renal metabolism of calcium resulted in the early observation of the calciuric effect of furosemide [Can J Physiol Pharmacol, 1968; Int J Clin Pharmacol, 1970]. Since the 1970s Dr. Schück was also interested in the function of residual nephrons, especially in relation to the clearance of amino acids [Nephron, 1978] and the effect of hemodialysis on tubular secretion in residual nephrons [Nephrol Dial Transplant, 1990].
Dr. Schück, inspired by his teacher Jan Brod, the pupil of Homer Smith, dedicated his lifelong interest to the functional examination of the kidney, starting from the insight into the antidiuretic action of vasopressin [Kidney Int, 1975] and a standardization of the desmopressin test of renal concentrating ability [Clin Nephrol, 1980] to the evaluation of glomerular filtration rate using cystatin C after liver transplantation [Liver Transplant, 2002] and in chronic renal insufficiency [Nephron, 2003]. The masterpiece of Dr. Schück was his monograph Examination of Kidney Function which was published not only in Czech (1970 and 1979), but also in English (1984) and Russian (1975 and 1981).

Professor Schück is one of the living legends of Czech nephrology, one of the founders of the Czechoslovak (and Czech) Society of Nephrology, dedicated teacher and scientist and a wise and modest man. Without his contribution, Czech nephrology would not have expanded so quickly in the 1990s after more than 40 years of the socialist system. It was clearly not by chance that Professor Schück became the first freely elected president of the Czechoslovak (then Czech) Society of Nephrology.

Let me thank Professor Schück for everything he has done for Czech nephrology and wish him to remain with us as active as he currently is for as long as possible.

Vladimir Tesar̆ 